\title{
On farm evaluation of the effect of low cost drip irrigation on water and crop productivity compared to conventional surface irrigation system
}

\author{
N. Maisiri ${ }^{\text {a }}$, A. Senzanje ${ }^{\text {b,* }}$, J. Rockstrom ${ }^{\text {c }}$, S.J. Twomlow ${ }^{\mathrm{d}}$ \\ a Department of Agricultural Engineering, Ministry of Agriculture, P.O. Box CY 639, Causeway, Harare, Zimbabwe \\ ${ }^{\mathrm{b}}$ Department of Soil Science and Agricultural Engineering, University of Zimbabwe, P.O. Box MP 167, Mt. Pleasant, Zimbabwe \\ ${ }^{\mathrm{c}}$ Department of Civil Engineering, University of Zimbabwe, P. O. Box MP 167, Mt. Pleasant, Zimbabwe \\ d ICRISAT-Matopos, P.O. Box 776, Bulawayo, Zimbabwe
}

Accepted 15 August 2005

Available online 29 September 2005

\begin{abstract}
This on-farm research study was carried out at Zholube irrigation scheme in a semi-arid agro tropical climate of Zimbabwe to determine how low cost drip irrigation technologies compare with conventional surface irrigation systems in terms of water and crop productivity. A total of nine farmers who were practicing surface irrigation were chosen to participate in the study. The vegetable English giant rape (Brassica napus) was grown under the two irrigation systems with three fertilizer treatments in each system: ordinary granular fertilizer, liquid fertilizer (fertigation) and the last treatment with no fertilizer. These trials were replicated three times in a randomized block design. Biometric parameters of leaf area index (LAI) and fresh weight of the produce, water use efficiency (WUE) were used to compare the performance of the two irrigation systems. A water balance of the inflows and outflows was kept for analysis of WUE. The economic profitability and the operation, maintenance and management requirements of the different systems were also evaluated. There was no significant difference in vegetable yield between the irrigation systems at 8.5 ton/ha for drip compared to 7.8 ton/ha in surface irrigation. There were significant increases in yields due to use of fertilizers. Drip irrigation used about $35 \%$ of the water used by the surface irrigation systems thus giving much higher water use efficiencies. The leaf area indices were comparable in both systems with the same fertilizer treatment ranging between 0.05 for surface without fertilizer to 6.8 for low cost drip with fertigation. Low cost drip systems did not reflect any labour saving especially when manually lifting the water into the drum compared to the use of siphons in surface irrigation systems. The gross margin level for surface irrigation was lower than for low cost drip irrigation but the gross margin to total variable cost ratio was higher in surface irrigation systems, which meant that surface irrigation systems gave higher returns per variable costs incurred. It was concluded that low cost drip systems achieved water saving of more than $50 \%$ compared to surface irrigation systems and that it was not the type of irrigation system that influenced the yield of vegetables significantly but instead it is the type of fertilizer application method that contribute to the increase in the yield of vegetables. It was recommended that low cost technologies should be used in conjunction with good water and nutrient management if higher water and crop productivity are to be realized than surface irrigation systems.
\end{abstract}

(C) 2005 Elsevier Ltd. All rights reserved.

Keywords: Low cost drip; Water productivity; Brassica napus; Fertigation; Water use efficiency

\footnotetext{
${ }^{*}$ Corresponding author. Tel.: +2634 303211; fax: +2634333880.

E-mail address: senzanje@agric.uz.ac.zw (A. Senzanje).
}

\section{Introduction}

The majority of the population in sub-Saharan Africa make their living from rainfed agriculture and depend to a larger extent on smallholder, subsistence agriculture for 
their livelihood and food security, for example, in Malawi, $90 \%$, in Botswana, $76 \%$, in Kenya , $85 \%$ and in Zimbabwe, $70-80 \%$ of the population. Lack of water in rainfed areas limits crop production to one, possibly two crops per year. Access to irrigation, which provides the means to cultivate an additional crop, is viewed as one of the best ways to boost productivity of small scale, dry land farming systems (Postel, 1998).

Surface irrigation methods are utilized in more than $80 \%$ of the world's irrigated lands yet the field level application efficiency is often only $40-50 \%$. In contrast, drip irrigation may have field level application efficiencies of $70-90 \%$, as surface runoff and deep percolation losses are minimized (Postel, 2000). For the above and many other reasons, drip irrigation is fast becoming popular in the developing world. In Zimbabwe, the area under drip irrigation has grown from a few hundred hectares in 1985 to over 30000 ha mainly in the horticultural industry (Senzanje, 1997). Drip irrigation may allow more crops per unit water to be grown and to allow crop cultivation in areas where insufficient water exists to irrigate by surface methods. This situation has enormous implications for the expansion into rain fed lands (von Westarp et al., 2004). In Zimbabwe drip irrigation is largely restricted to the large-scale commercial farming community and has evolved to become a knowledge intensive, technology oriented operation such that smallholder farmers have not adopted it extensively. This is a major cause of concern because the smallholder farmers constitute a large proportion of the farming community in Zimbabwe - over 95\% of the total number of farmers (disregarding size of farms) or $65 \%$ share of the total agricultural land (ZAPF, 1995). Conventional drip systems are expensive, fairly complex and delicate and require pressures above 1 bar. Such systems cannot be afforded by and are not appropriate for the smallholder farmer (Senzanje, 1997). Smallholder farmers require affordable, robust, simple and low-pressure drip system for them to adopt and realize the benefits that drip can offer (Senzanje, 1997).

A non-governmental organization (NGO) called linkages for economic advancement of the disadvantaged (LEAD), is distributing low cost drip kits in Zimbabwe. These low head (low energy requirement) low cost drip irrigation technologies were being introduced to bridge dry spells, mitigate droughts and ensure food security (Chigerwe et al., 2003). These kits however have not been widely studied. The only recent studies on the different kits have been the work carried out in a laboratory to test the performance of these kits by Chigerwe et al. (2003) and by Senzanje et al. (2004) to test the operational limits of such drip kits. The tests by Chigerwe et al. (2003) found that in the laboratory the imported kits (Netafim $^{\circledR}$, Plastro ${ }^{\circledR}$, IDE $^{\circledR}$ and EIN-TAL $\left.{ }^{\circledR}\right)^{1}$ had superior quality and work-

\footnotetext{
${ }^{\circledR}$ The use of trade names is for information purposes only and does not indicate endorsement of a product.
}

manship on all components than locally available kits. However, they found that one locally manufactured kit had excellent and stable uniformities of about $91 \%$ even at very low heads of between $0.5-3 \mathrm{~m}$. Apart from these laboratory studies, no field work has been done in Zimbabwe to evaluate how these low cost drip systems perform in the field in terms of efficiencies, water productivity, acceptability, uptake by local farmers, operation and maintenance of these kits and how farmers in the rural set-up to which these kits were distributed would be able to cope with the operation and management requirements of such newly introduced technology. This study focused on comparing, in the field, one of the low cost drip irrigation systems that brought about stable uniformities in a laboratory (Plastro kit ${ }^{\circledR}$ ) with conventional surface irrigation systems and to investigate the effect of these two irrigation systems in combination with fertilizer treatments, on crop performance and water use (crop and water productivity). Through on farm research, the main objectives of the study were:

(i) To investigate the effect on crop and water productivity of low cost, low head drip irrigation compared to conventional surface irrigation systems.

(ii) To investigate the effect of low cost drip fertigation on water and crop productivity.

(iii) To investigate the operational and management requirements of the low cost drip technology in a rural set-up.

(iv) To assess the economic viability of using low cost, low head drip systems.

\section{Materials and methods}

\subsection{Experimental site}

The field experiments were conducted in winter from start of April to mid-June 2004 at Zholube irrigation scheme in Ward 1 of Insiza district in Matebeleland South Province (Grid Ref. $33^{\circ}$ E $17^{\circ} \mathrm{N}$ ) in the Mzingwane subcatchment of Limpopo basin in Zimbabwe. The irrigation scheme covering a total of 12 ha was developed in 2001 by the non-governmental organization World Vision to contribute towards fighting against drought and poverty. The water used for irrigation came from the Zholube dam, $250 \mathrm{~m}$ upstream of the irrigation scheme. The irrigation scheme is in a hot agro climate (Natural Region 5) with average annual rainfall of less than $250 \mathrm{~mm}$ and mean annual maximum temperatures of $30^{\circ} \mathrm{C}$ (Unganani, 1996). The soils were sandy-clay loams with a pH $5.4( \pm 0.3)$, soil bulk density was $1.60 \mathrm{~g} / \mathrm{cm}^{3}$ for the top $10 \mathrm{~cm}$ and the average slope of the land was $3 \%$. The major crops that are grown on the scheme are maize as the main summer crop, and also sugar beans, wheat and horticultural crops like tomatoes, rape cabbage, onions, gem squash and okra. 
The field experiments were conducted with a total of nine farmers (out of 42 in the scheme) who volunteered to participate in the research study. There were five men and four women in the study and their ages ranged from 27 to 77 years. Each farmer had one drip kit commanding an area of $100 \mathrm{~m}^{2}$ and another $100 \mathrm{~m}^{2}$ of surface irrigation set for the experiment. All the participants were fulltime smallholder farmers. Farming in this irrigation scheme formed part of their only hope to earn a living apart from gold panning which is also prevalent for people with no access to irrigation plots.

\subsection{Treatments and experimental plot layout}

The experiment was set-up using two irrigation methods with three different fertilization treatments as shown in Table 1.

The irrigation methods were:

(i) A low cost drip irrigation (LCD): Manufactured by Plastro $^{\circledR}$ (Israel), and distributed by LEAD Zimbabwe (flow rate $=0.81 / \mathrm{h}$ and with emitter spacing of $30 \mathrm{~cm}$ operating at $1 \mathrm{~m}$ head through $10 \times 10 \mathrm{~m}$ laterals).

(ii) Conventional surface irrigation $(\mathrm{CON})$ : Using 3 poly plastic siphons $63 \mathrm{~mm}$ in diameter and a discharge of $1.2 \mathrm{l} / \mathrm{s}$ each giving a total of $3.6 \mathrm{l} / \mathrm{s}$ per border which was $50 \mathrm{~m}$ in length and $2 \mathrm{~m}$ wide.

These treatments were replicated three times to give a total of 9 drip kits, and six conventional irrigation plots.

Plot layout was as given in Fig. 1. The field was divided into two to accommodate the border and drip irrigation

Table 1

Fertiliser treatments applied to each irrigation method

\begin{tabular}{lll}
\hline Irrigation system & Fertilizer & Combination \\
\hline Low cost drip & No fertilizer & LCD + NF \\
Low cost drip & Granular fertilizer & LCD + GF \\
Low cost drip & Liquid fertilizer & LCD + F \\
Conventional surface & No fertilizer & CON + NF \\
Conventional surface & Granular fertilizer & CON + GF \\
\hline
\end{tabular}

plots. A drain was constructed in the middle of the field to drain out all the excess water, if any, from the border and to inhibit water flowing from the border into the drip kits. A $2 \mathrm{~m}$ buffer was created between the drain and the drip plots to restrict soil water interactions between the two systems. The different treatments were as shown on the plot layout. A drip kit layout of the lateral and emitters is shown in Fig. 2 below. Each lateral served two rows of crops.

\subsubsection{Crop management}

Kale, popularly known as English giant rape (Brassica napus) was chosen as the crop as it is widely grown in the area by the farmers. Sowing of seeds was done on the 5 th of March 2004 in a seedbed. Transplanting of rape at spacing of $30 \mathrm{~cm}$ inter-row and $30 \mathrm{~cm}$ between rows was carried out on the 1st of April 2004. The plant population was 666 plants per plot (66666 plants per hectare). Recommended plant protection measures such as scouting, spraying with Diamethoate $40 \mathrm{EC}$ as well as regular weeding in the conventional plots were undertaken to produce a disease and weed free crop. Harvesting of the crop started on the 3rd of May till the end of May giving a total of five harvests.

\subsubsection{Fertilizer application and fertigation}

One drip kit (as shown in Fig. 2) served as one treatment, for example, LCD and no fertilizer (LCD + NF). The levels for granular fertilizer were based on recommendations on application rates from the Department of Research and Extension (AREX) for Insiza district (100 kg/ ha basal fertilizer and $200 \mathrm{~kg} / \mathrm{ha}$ of ammonium nitrate as top dressing). The composition of the basal fertilizer was $5 \% \mathrm{~N}, 18 \% \mathrm{P}_{2} \mathrm{O}_{5}, 10 \% \mathrm{~K}_{2} \mathrm{O}, 8 \% \mathrm{~S}$ and $0.25 \% \mathrm{~B}$. Liquid fertilizer application rates were based on fertigation recommendations from LEAD Zimbabwe through their IDE guidelines ( $4 \mathrm{~kg} / \mathrm{kit}$ which is equivalent to $400 \mathrm{~kg} / \mathrm{ha}$ ). The chemical composition of the liquid fertilizer used for fertigation was $8.41 \% \mathrm{~N}, 6.2 \% \mathrm{P}_{2} \mathrm{O}_{5}, 15.6 \% \mathrm{~K}_{2} \mathrm{O}, 7.2 \% \mathrm{~S}$, $0.02 \% \mathrm{~B}, 0.3 \% \mathrm{Zn}$ plus microelements. In the drip plots, soluble fertilizer was applied through the drip system in a split operation as per recommendations from LEAD, that is, $1 \mathrm{~kg} /$ drip kit $\left(100 \mathrm{~m}^{2}\right)$ every fortnight commencing 1 week after transplanting for four times.

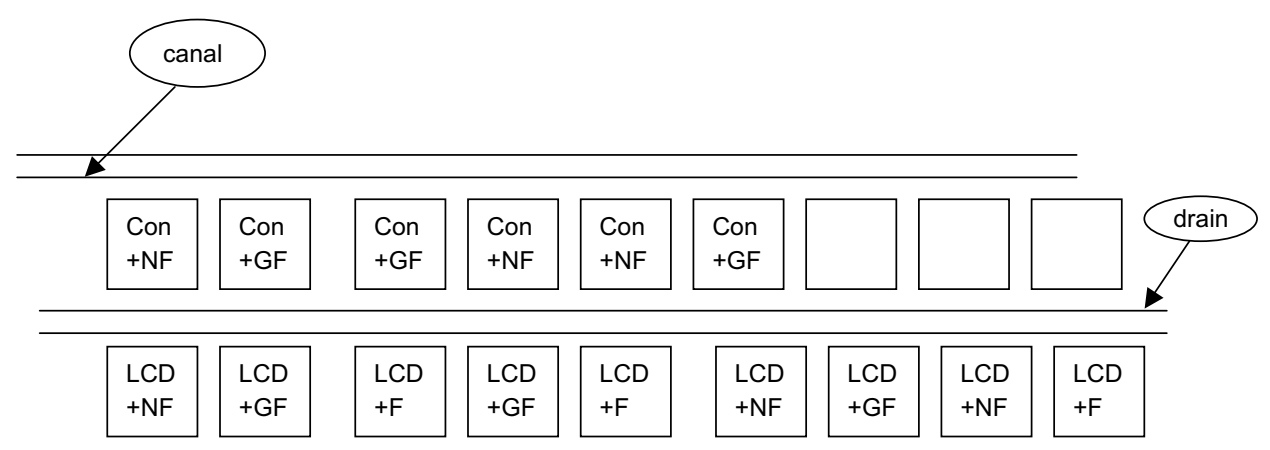

Fig. 1. Field plots experimental layout of treatments. 


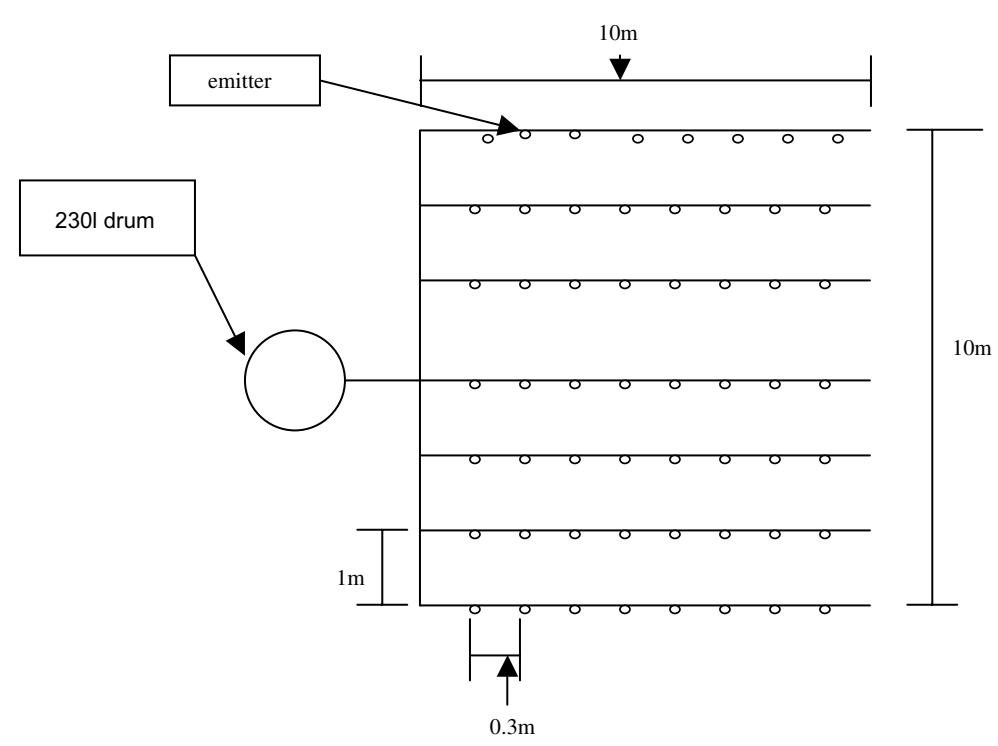

Fig. 2. Low cost drip (LCD) unit set-up (not to scal).

\subsubsection{Irrigation scheduling}

2.2.3.1. Border irrigation scheduling. The farmers followed their usual daily practice and the irrigation cycle was determined by how long it took the other farmers to complete their turns until such a time that it was the farmer's turn. On average it took about 7 days to complete the irrigation cycle. This worked out to be 9 irrigations per plot per vegetable cropping season. Each irrigation event lasted for 9$12 \mathrm{~min}$. The volume of water applied was calculated from observing farmers undertaking irrigation and noting the number of siphons in operation per border multiplied by the individual siphon discharge and duration of irrigation. From this, the depth of water applied was found by dividing the volume applied by the area irrigated and this came to about $15 \mathrm{~mm}$ of water. The irrigation scheduling was based on rotation of supply such that the amount applied was not really fixed to the water demand. Strict monitoring was however implemented to ensure that farmers adhered to practice.

2.2.3.2. Drip irrigation scheduling. Due to non-availability of scheduling equipment such as tensiometer, pan evaporation or soil moisture retention curves to the local farmers, IDE recommendations to Zambian and Nepalese farmers and FAO Manual (2003) were used to provide watering guidelines to Zholube farmers. IDE guidelines for Zambian farmers (Daka and Borsma, 1999) recommended filling of the tank twice a day once in the morning and once in the afternoon to irrigate vegetables which require $11 /$ day/ plant. This worked out to be $460 \mathrm{l} /$ day per plot every two to three days for water applications. Over the season the total volume of water applied was $7.84 \mathrm{~m}^{3} /$ plot. For Nepal the following equation was used to offer guidelines to the farmers:

$W=\frac{0.4983 D^{2} P_{\mathrm{f}} \mathrm{ET}_{0}}{\mathrm{EF}}$ where $W^{2}$ is the daily water requirement per plant (gallons/ day plant), $D$ is the diameter of the plant canopy (ft), $P_{\mathrm{f}}$ is the plant factor, $\mathrm{ET}_{0}$ is the potential evapotranspiration (inches per day), and EF is the irrigation frequency (days). The $\mathrm{ET}_{0}$ (potential evapotranspiration) for Nepal ranges from 3 to $4 \mathrm{~mm} /$ day. This range of $\mathrm{ET}_{0}$ is comparable to the range of $4 \mathrm{~mm} /$ day in the month of May for the Zholube study area, therefore the relationship was adapted for our study. The set time (duration of irrigation) at peak was determined using recommendations from FAO (2003) irrigation manual which applies the following expression:

$S_{\mathrm{t}}=\frac{I_{\mathrm{rg}}}{N q_{\mathrm{e}}}$

where $S_{\mathrm{t}}$ is daily hours of operation, $I_{\mathrm{rg}}$ is gross irrigation requirement, $N$ is the number of emitters, $q_{\mathrm{e}}$ is the emitter discharge $(1 / \mathrm{h})$. With the two recommendations from Nepal guidelines and calculations we recommended our farmers to irrigate three times a week with $2-3$ drums a day (each drum being 2301 ).

\section{Measurements}

The following parameters were measured during the study: water balance components such as rainfall, volume of water applied, runoff and soil volumetric water content. Transpiration was estimated from the yield obtained and the water use efficiency for productive flow. Soil evaporation was estimated using Pilbeam's relations (Loomis and Connor, 1992). Biometric parameters, such as leaf area index, height and yield were measured. Operation and

\footnotetext{
${ }^{2}$ Although the parameters are defined in empirical units they were converted to metric in the calculation of the irrigation depth required.
} 
maintenance and economic profitability were assessed and used to evaluate the performance of the different irrigation methods with the different fertilizer treatments.

\subsection{Water balance components}

Any rainfall that occurred was measured using a rain gauge. Runoff was considered negligible due to the localized nature of these drip systems and considered no runoff in the surface irrigation system since the system had closed borders. Irrigation water was accounted by the actual volume of water applied. The change in the amount of water stored was estimated by determining the soil moisture levels at the beginning and end of the irrigation season. The amount of water stored was the difference between the final storage and the initial storage. This was done for different depths $0-10 \mathrm{~cm}, 10-20 \mathrm{~cm}, 30-40 \mathrm{~cm}$ and $40-50 \mathrm{~cm}$ for both systems at the beginning and end of the season. Transpiration was obtained indirectly from the yield that is produced using the following relation:

$$
\mathrm{WUE}_{\mathrm{t}}=Y / T
$$

where $Y$ is the yield $(\mathrm{kg} / \mathrm{ha}), T$ is the transpiration in $\mathrm{m}^{3}$ and $\mathrm{WUE}_{\mathrm{t}}$ is water productivity (transpiration) $\left(\mathrm{kg} / \mathrm{m}^{3}\right)$. The value of the $W E_{t}$ used was $4275 \mathrm{~kg} / \mathrm{ha} / \mathrm{mm}$ (Tiwari et al., 2003). This figure was taken from work carried out on cabbage (Brassica oleracae ver capitata) which is in the same family with rape. Soil evaporation can be estimated by use of lysimeters but in this study an estimation of soil evaporation was based on scientific work done by Pilbeam et al. (1995) in Kenya and Nyamudeza (1998) in the Save Valley in the lowveld of Zimbabwe.

\subsection{Operation and maintenance issues}

A questionnaire was administered to the nine out of the forty two farmers to get their opinions and perceptions on the use of drip kits especially regarding labour requirements, operation and maintenance requirements, spares and water management aspects.

\subsection{Economic profitability}

An economic analysis was done to compare the inputs and the outputs from the different irrigation system and fertilizer treatments. The economic viability was calculated on the area of each drip kit $\left(100 \mathrm{~m}^{2}\right.$ field size and 666 plants at a spacing of $30 \mathrm{~cm} \times 30 \mathrm{~cm}$ ). The amount of rape produced was based on the average yield from drip kits with similar treatments. Costs were divided into capital and variable costs. Variable costs included seed, fertilizer, chemicals, irrigation water and labour costs incurred in land preparation, weeding, irrigating and filling of the drums with water. Family labour was considered at a rate of 129 labour days/ha (MoLARR, 2004). Time required to fill the tank was actually recorded by the individual farmers during the research exercise. Costs associated with operation and maintenance, repair and depreciation were assumed at $10 \%$ of the cost of the kit based on standard economic procedure. Revenue was obtained from the sales of the bundles produced and each bundle was sold for $\mathrm{Z} \$$ 1000 (US\$ 0.20). ${ }^{3}$

\section{Results}

\subsection{Seasonal water balance}

A total of $7.87 \mathrm{~m}^{3}(78.7 \mathrm{~mm})$ of water was used for $100 \mathrm{~m}^{2}$ plot drip irrigation and $23.88 \mathrm{~m}^{3}(238.8 \mathrm{~mm})$ of water for surface irrigation per season. There were no rainfall events during the vegetable growing season. The total soil evaporation from the drip and surface irrigation plots was $2.75 \mathrm{~m}^{3}(27.5 \mathrm{~mm})$ and $8.72 \mathrm{~m}^{3}(87.2 \mathrm{~mm})$, respectively per season. The total transpiration from the drip systems was $2 \mathrm{~m}^{3}(20 \mathrm{~mm})$ and $1.85 \mathrm{~m}^{3}(18.5 \mathrm{~mm})$ for surface irrigation system. The change in water stored in the root zone from the beginning to the end of the season was $0.86 \mathrm{~m}^{3}$ $(8.6 \mathrm{~mm})$ for surface and $0.258 \mathrm{~m}^{3}(2.58 \mathrm{~mm})$ for drip irrigation system (Fig. 3).

\subsection{Water productivity}

The calculated water productivity (irrigation) $\mathrm{PW}_{\text {irr }}$ is as given in Table 2.

Low cost drip with fertigation had the highest water productivity at $10.8 \mathrm{~kg} / \mathrm{m}^{3}$ and conventional surface irrigation had the lowest at $2.4 \mathrm{~kg} / \mathrm{m}^{3}$. In general drip irrigation system had higher water productivities regardless of the type of fertilizer treatment that was applied. The highest yield levels were obtained from drip irrigation with fertigation and the least yields were obtained from drip with no fertilizer (Table 2). In general drip with fertilizer had higher yields than conventional surface irrigation with fertilizer.

Leaf area Index (LAI) for drip treatments were generally higher than conventional surface irrigation with the same fertilizer treatment. However, drip with fertigation gave the highest leaf area index of 6 compared to 0.75 for conventional surface irrigation with no fertilizer.

\subsection{Drip kit operation}

Drip systems proved to be labour intensive especially in filling of the drum compared to conventional surface irrigation system. All the farmers found the drip kits easy to operate. All the respondents were able to grow vegetables enough for household consumption from the drip kits, however the surplus produce was not enough for them to meet the cost of the following season inputs.

\footnotetext{
${ }^{3}$ 1US\$ equivalent to $\mathrm{Z} \$ 5000$ used as the exchange rate.
} 

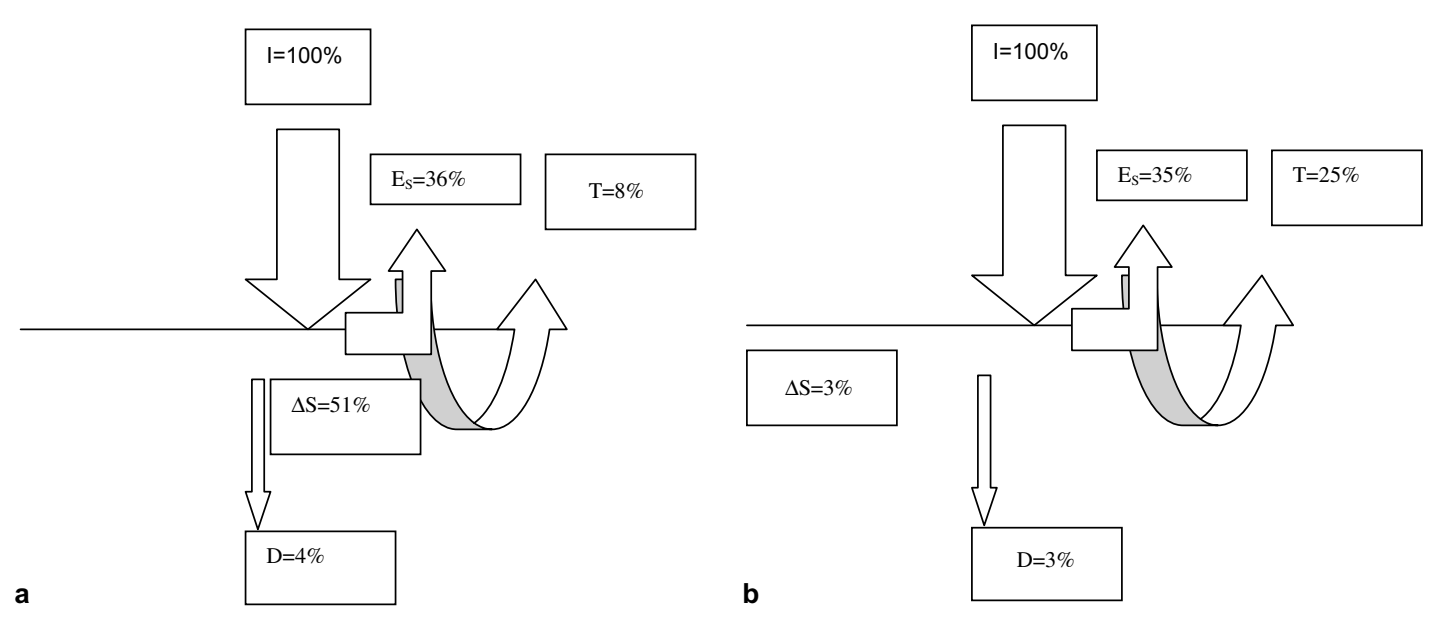

Fig. 3. Summary of the water partitioning between the two irrigation systems (a) surface, and (b) drip irrigation. Key: $I=$ irrigation, $E_{\mathrm{s}}=$ soil evaporation, $T=$ transplantation, $\Delta S=$ change in soil water storage, and $D=$ deep percolation.

Table 2

Water productivities for drip and surface irrigation methods with different fertilizer applications

\begin{tabular}{lccc}
\hline Treatment & Volume used $\left(\mathrm{m}^{3}\right)$ & Yield $(\mathrm{kg})$ & $\mathrm{PW}_{\text {irr }}\left(\mathrm{kg} / \mathrm{m}^{3}\right)$ \\
\hline LCD + NF & 7.868 & 51.6 & 6.5 \\
LCD + GF & 7.868 & 85.1 & 10.82 \\
LCD + F & 7.868 & 100.8 & 12.8 \\
CON + NF & 23.88 & 57.9 & 2.4 \\
CON + GF & 23.88 & 78.87 & 3.3 \\
\hline
\end{tabular}

\subsection{Economics}

Low cost drip system with granular fertilizer gave the highest gross margin to total variable cost (GM/TVC) ratio of 2.47. This was followed by low cost drip with fertigation with a GM/TVC ratio of 2.37 and the least ratio was found in low cost drip with no fertilizer treatment.

\section{Discussion}

\subsection{Water balance}

\subsubsection{Irrigation}

Surface irrigation method used $23.88 \mathrm{~m}^{3}(238.8 \mathrm{~mm})$ of water compared to $7.87 \mathrm{~m}^{3}(78.7 \mathrm{~mm})$ of water to irrigate a plot size of $100 \mathrm{~m}^{2}$ of vegetables for the whole season. The main reason for such a difference is that in surface irrigation systems, $100 \%$ of the area is wetted unlike in the drip systems where only $30 \%$ of the area is wetted. The high water application depth achieved for surface irrigation system of $40 \mathrm{~mm}$ in some weeks was as a result of the management practice of the farmers in cutting off the water supply to the border. Water supply was only cut when the waterfront had advanced to the end of the border. This implied that in some cases water application took a long time, depending on the evenness of the border slope, resulting in the up stream reaches of the border having a longer contact time leading to higher irrigation depths compared to the downstream end of the border. General border irrigation management requirements says the water should be cut off when the advance front is three quarters the length of run $(3 / 4$ rule).

\subsubsection{Transpiration}

The total transpiration for drip and surface irrigation methods were comparable. This was the case since the amount of transpiration is mainly determined by the total amount of ground cover and canopy. The plant populations in the two systems were the same.

\subsubsection{Evaporation from the soil}

A total of $8.72 \mathrm{~m}^{3}(36.52 \%$ of the total inflow) was lost as soil evaporation in the surface irrigation systems and a total of $2.75 \mathrm{~m}^{3}(34.9 \%)$ in drip systems. These figures are comparable with figures reported by Rockstrom (1999) for rain fed system of $30-50 \%$. These soil evaporation figures could have been somewhat overestimated because during the application of the Pilbeam equation, the following assumptions were made which are not always valid: it was assumed that the predominant factor to soil evaporation depletion is the number of days after an irrigation or rainfall event. Some other minor factors were ignored that could have brought some slight adjustments such as the level of the soil moisture deficit in the soil (Nyagumbo, 2002). One assumption that was also mainly used which according to a number of researchers has been accepted and adopted (for example, Howard and Lloyd, 1979) is that for precipitation or rainfall event greater than the maximum $\mathrm{ET}_{0}$ then the actual evaporation equals the potential rate. The potential rate was used as the soil evaporation on the day after an irrigation event and for day 1 onwards Pilbeam et al. (1995) equation which gives the soil evaporation as a function of time was used. The figures formed a good basis for comparing the two systems since the approach used in both cases was the same. Wallace (1993) reported soil water evaporation of around $2.4 \mathrm{~mm} /$ 
day $16 \mathrm{~h}$ after a rainfall event. In this study daily soil evaporation ranged from $3.5 \mathrm{~mm} /$ day the day after an irrigation event to below $1 \mathrm{~mm} /$ day 3 to 4 days after. This agrees well with findings from research studies by Wallace (1993) on models of evaporation on rain fed systems on semi-arid lands. On a seasonal scale Wallace (1993) reported that $35 \%$ of the total inflow is lost through soil water evaporation, which agrees very well with the results obtained in this study of $36.5 \%$.

\subsection{Water productivity}

The lowest water productivity was obtained in the surface irrigation system that had no fertilizer. Generally, drip irrigation had higher water productivity regardless of fertilizer treatment. For each irrigation system (LCD and CON) water productivity increased in the order of irrigation with no fertilizer, followed by irrigation with fertilizer, and the highest being irrigation with fertigation.

Low cost drip systems generally gave higher water productivities compared to surface irrigation systems. This was mainly because of the higher volumes of water applied in the surface irrigation system compared to drip irrigation systems as discussed under the volume of water applied. Higher productivity levels were experienced in treatments with fertilizer than those with fertilizer to the increases in yields due to the fertilizer application, In short the high water productivity levels in drip with fertilizer and with fertigation is a combination effect of the nitrogen application through fertilizer and water saving through use of low cost drip.

\subsection{Biometric parameters}

\subsubsection{Yield}

Low cost drip systems with fertigation had the highest yield levels of $100 \mathrm{~kg} / 100 \mathrm{~m}^{2}$ and the least yield of $51.6 \mathrm{~kg} / 100 \mathrm{~m}^{2}$ was obtained from the low cost drip system with no fertilizer. Statistically, there was no significant difference between treatments with same fertilizer treatment and different irrigation system at the 0.05 level (using the least significance difference approach). This showed that the type of irrigation system does not affect the level of yield statistically but it is the type of fertilizer method which contributed to the level of yield achieved. This was because of the fact that despite the method of water application, water was however not a limiting factor as the full crop water requirement were met in both systems. The method of fertilizer application affected the yield in that fertigation had a better application method as the fertilizer was injected through the water supply directly to the plant and this was not done once off, as in the case of granular fertilizer, but in split application to address the nutrient requirement for foliage development through out the growing season. The yield levels of rape in fertilized treatments were comparable with the yield provided by FAO (2003) on attainable yields of 10-20 ton/ha depending on management practice.

\subsubsection{Leaf area index (LAI)}

The LAI was high in drip system because of the fertigation which gave better leaf production compared to surface irrigation. LAI index is an important component in vegetables because it is the harvested yield which in turn is sold to give the farmer returns. In such a case, drip irrigation offers advantages to the farmer in terms of yield.

\subsection{Operation and maintenance}

Results show that low cost drip irrigation systems were easy to operate, manage and maintain. The labour requirements were high and $80 \%$ of farmers in the area complained when using these low cost low head drip irrigation systems because of the labour requirements involved. The farmers suggested that the design of the low cost drip system should be looked at to accommodate more crops per unit area. According to the Keller (1990) scale, which ranks and give a score to different irrigation technologies according to some key parameters such as sustainability, easy of operation, risk and durability; low cost drip technology can be adopted by our farmers as it has passed the key criteria used that looks at issues of operation, sustainability, easy of operation, risk of crop failure and durability.

The returns obtained from the sale of produce were used to buy food for consumption, pay for school fees, but farmers said the money was not enough to buy inputs for the following season. The major reason why most farmers said the money could not buy inputs for the next season was that they thought if such information got to the nongovernmental organisation World Vision that had been assisting with food and inputs then World Vision would withdraw the assistance. This was the case because from the gross margin levels obtained, it was evident that the amount of money was enough to buy food, pay for school fees for primary education in rural areas and buy their inputs for the next season. The questionnaire approach had the shortfall that some farmer's response to issues to do with affordability was biased towards what they thought the research findings would be used for. Some farmers thought the research was an exercise similar to the poverty assessment study by government in a bid to assist the communities and in that way some responses were influenced by these external forces.

\subsection{Economic analysis}

Low cost drip with fertigation had the highest gross margin of Z\$70 910 (US\$15) levels followed by low cost drip with granular fertilizer at $Z \$ 59310$ (US\$11) then conventional with granular fertilizer at Z\$53 019 (US\$10.60) and the least gross margin was from low cost drip with no fertilizer at Z\$40 010 (US\$8). The scenario was however 
different when considering the gross margin per total variable cost ratio which actually shows the amount of revenue generated per amount of variable cost borne. Low cost drip with granular fertilizer had the highest returns per total variable cost compared to other treatments. This was followed by the low cost drip with fertigation. This was mainly because liquid fertilizer was much more expensive than granular fertilizer but did not result in a significant increase in yield.

\section{Conclusions}

From the study, and in relation to the objectives set, it can be concluded that:

(i) Water savings of more than $50 \%$ were achieved in low cost drip systems compared to surface hence higher water productivities in drip.

(ii) Low cost drip irrigation alone did not result in significantly higher crop productivities but an integrated approach that involved nutrient management and proper water management using low cost drip resulted in significantly higher crop productivity and higher gross margin levels compared to conventional surface irrigation system.

(iii) With proper marketing and proper agronomic and technical support low cost technologies can be adopted by smallholder farmers. Low cost irrigation systems can change family lifestyles, increase people's incomes, create employment and go a long way towards food security and improved nutrition.

(iv) Training, agronomic support and back up support is crucial in the implementation of a new innovation or technology in an area.

\section{Recommendations}

From the study, the following recommendations are made:

(i) Recommend an integrated approach in water and nutrient management if higher water and crop productivities are to be achieved, that is, the newly introduced innovations such as the low cost low head drip irrigation systems should be used in conjunction with proper soil fertility management techniques.

(ii) Operation, maintenance and management requirements of newly introduced technology or interventions need to be looked at closely since these have a big bearing on the take up of the technology by communal farmers and whether the technology will be used sustainability after the withdrawal of the initiator or the donor agent.

(iii) Recommend further studies in the market opportunities, marketing and handling of produce from these kits in a bid to add value and make them sustainable.

\section{Acknowledgements}

The authors are grateful to Waternet and Challenge Programme for Water for Food for financial support and the farmers in Zholube for their time and help during the study.

\section{References}

Chigerwe, J., Manjengwa, N., Van der Zaag, P., Zhakata, W., 2003. Low head drip irrigation kits and treadle pumps for smallholder farmers in Zimbabwe - a technical evaluation based on laboratory tests. Physics and Chemistry of the Earth 29 (15-18), 10491059 .

Daka, A.E., Borsma, A.J., 1999. An introduction to low cost drip irrigation for small scale farmers. A Practical Guide for Users to Achieve Water Saving and Maximize Crop Yield Per Unit of Water. International Development Enterprises, Lusaka, Zambia.

FAO, 2003. Food and Agriculture Organization Irrigation Manual, second ed. Rome, Italy.

Howard, K.W.F., Lloyd, J.W., 1979. The sensitivity of parameters in the Penman evaporation e.g. nations and direct recharge balance. Journal of Hydrology 41, 329-344.

Keller, J., 1990. Modern irrigation in developing countries. In: Proceedings of the 14th International Congress on Irrigation and Drainage. Rio de Janeiro, Argentine, April-May 1990. International Congress on Irrigation and Drainage, Chanakyapuri, New Delhi, India.

Loomis, R.S., Connor, D.J., 1992. Crop Ecology: Productivity and Management in Agricultural Systems. Cambridge University Press, UK, p. 520.

MoLARR, 2004. Ministry of Lands, Agriculture and Rural Resettlement, Economics Branch Report. Government of Zimbabwe. Harare, Zimbabwe.

Nyagumbo, I., 2002. The effects of three tillage systems on seasonal water budgets and drainage of two Zimbabwean soils under maize. DPhil, Faculty of Agriculture University of Zimbabwe.

Nyamudeza, P., 1998. Water and fertility management for crop production in semi-arid Zimbabwe. DPhil School of Biological Sciences, University of Nottingham Loughborough. UK.

Pilbeam, C.J., Daamen, C.C., Simmonds, L.P., 1995. Analysis of water budgets in semiarid lands from soil water records. Experimental Agriculture 31, 131-149.

Postel, S., 1998. Pillar of Sand: Can the Irrigation Miracle Last. Publ. WW Norton and Co, New York

Postel, S., 2000. Redisigning irrigated agriculture. In: Starke, L. (Ed.), State of the World 2000. Publ. WW Norton and Co, New York, pp. 39-58.

Rockstrom, J., 1999. On-farm green water estimates as a tool for increased food production in water scarce regions. Physics and Chemistry of the Earth (b) 24, 375-383.

Senzanje, A., 1997. Developing and testing drip irrigation systems technologies for smallholder farmersProceedings of the Joint International Conference on Agricultural Engineering and Technology Exhibition, vol. I. Bangladesh Society of Agricultural Engineers, Dhaka, Bangladesh.

Senzanje, A., Motsi, K., Rwakatiwana, P., 2004. Assessing the technical performance and operational limits of a low cost drip irrigation system for peri-urban and smallholder farmers. Discovery and Innovation 16 (1 \& 2), 85-97.

Tiwari, K.N., Singh, A., Mal, P.K., 2003. Effect of drip irrigation on yield of cabbage (Brassica oleracae var. capitata) under mulch and nonmulch conditions. Agricultural Water Management 64, 143 160.

Unganani, L.S., 1996. Historic and future climatic changes in Zimbabwe. Climatic Research 6, 137-145. 
von Westarp, S., Chieng, S., Schreier, H., 2004. A comparison between low cost drip irrigation, conventional drip irrigation and hand watering in Nepal. Agricultural Water Management 64, 143-160.

Wallace, J.S., 1993. The measurement and modelling of evaporation from semiarid lands. In: Sivakumar, M.V.K., Wallace, J.S., Renard, C., Giroux, C. (Eds.), Soil Water Balance in the Sudano-Sahelian Zone.
Proceedings of the International Workshop, Niamey, Niger, February 1991. IAHS Publication No. 1999. IAHS Press, Institute of Hydrology, Wallingford, UK, pp. 131-148.

ZAPF, 1995. Zimbabwe Agricultural Policy Framework 1995-2020. Ministry of Agriculture, Zimbabwe, Government of Zimbabwe, Harare, Zimbabwe. 